\title{
Basal cell carcinoma appearing in a facial nevus sebaceous of Jadassohn: dermoscopic features
}

\author{
Carcinoma basocelular aparecendo em um nevo sebáceo de Jadassohn: \\ características dermatoscópicas
}

\author{
Maria Leonor Enei ${ }^{1}$ \\ Gustavo Valdés ${ }^{3}$
}

\author{
Francisco Macedo Paschoal ${ }^{2}$ \\ Rodrigo Valdés ${ }^{3}$
}

\begin{abstract}
The nevus sebaceous of Jadassohn usually affects the face or scalp. It tends to evolve in three stages, and the final stage is characterized by the appearance of tumours. We present the case of a facial nevus sebaceous of Jadasshon in which a basal cell carcinoma developed. We also explore the diagnosis of this disease, which was established through dermoscopy, and propose using this technique in the clinical follow-up of this type of hamartoma, thereby allowing the early detection of cancer development. Keywords: Carcinoma, basal cell; Dermoscopy; Neoplasms, basal cell; Nevus, sebaceous of Jadassohn

Resumo: O nevo sebáceo de Jadassohn geralmente afeta a face ou o couro cabeludo. A sua tendência natural é evoluir em três estágios, sendo que o estágio final é caracterizado pelo aparecimento de tumores. Apresentamos o caso de um nevo sebáceo de Jadassohn na face a partir do qual um carcinoma basocelular se desenvolveu. Também abordamos o diagnóstico dessa doença, estabelecido por meio da dermatoscopia. Sugerimos a utilização dessa técnica no acompanhamento clínico desse hamartoma, permitindo assim a detecção precoce de um câncer.

Palavras-chave: Carcinoma basocelular; Dermoscopia; Neoplasia de células basais; Nevo sebáceo de Jadassohn
\end{abstract}

\section{INTRODUCTION}

The nevus sebaceous of Jadassohn (NSJ) is a congenital hamartoma that usually affects the face or scalp. ${ }^{1}$ The natural tendency of an NSJ is to evolve in three stages, and the final stage is characterized by the appearance of tumours.

Dermoscopy is a non-invasive imaging technique that has proved useful for diagnosing a number of skin lesions through the in vivo observation of distinct structures that are considered highly diseasespecific. The early stages of an NSJ are specifically characterized by the presence of yellow lobed struc- tures, bright yellow spots that are not associated with hair follicles, and surrounding thin telangiectasias (without branching) in lesions of longer evolution. ${ }^{2,3}$

We report the case of a tumor-stage NSJ and highlight its dermoscopic findings, which were characteristic of both the nevus and its associated cancer. These findings allowed us to diagnose a basal cell carcinoma (BCC). To the best of our knowledge, this is the first time that such an association has been documented using this technique.

\footnotetext{
Received on 04.07.2011.

Approved by the Advisory Board and accepted for publication on 29.12.2011.

Work conducted at the Private Practice - Iquique, Chile.

Conflict of interest: None

Financial funding: None

Specialization in Dermatology from the Brazilian Society of Dermatology - Private Practice - Iquique, Chile.

Assistant Professor of Dermatology - Faculdade de Medicina do ABC (ABC School of Medicine) - FMABC - São Paulo (SP), Brazil.

Specialist in histopathology - Institute of Histopathology, Histonor - Antofagasta, Chile. 


\section{CASE REPORT}

We present the case of a 30-year-old male patient of skin photo type IV who reported recent changes in the pigmentation of a lesion in his right eyebrow tail, which had remained unchanged since birth.

Upon examination, we observed a 20 -mm-longelliptical plaque with a papulose surface and yellowish-pink coloration; these features were compatible with an NSJ. There was also a 6-mm, blackish, hyperpigmented area located on the edge of the lesion (Figure 1).

During dermoscopic evaluation, it became evident that the pigmented area contained multiple bluegrey, ovoid structures of various sizes, both grouped and unconnected, including some branched telangiectasias (Figure 2). These findings are characteristic of BCC, and the absence of evidence indicating melanocytic lesions led us to the diagnosis of this type of cancer. The remainder of the lesion was composed of yellowish globular structures, which were grouped into evenly distributed clusters and surrounded by thin telangiectasias, as previously described for sebaceous hyperplasia (Figure 3).

A histopathologic study of the entire tissue confirmed the presence of a solid, cystic basal cell carcinoma within the NSJ (Figure 4).

\section{DISCUSSION}

An NSJ is a hamartoma that progresses to tumor stage in $20 \%$ to $30 \%$ of cases. NSJs are most often benign neoplasms. ${ }^{4}$ The development of a malignant neoplasm is rare and largely involves basal and squamous cell carcinomas. According to recent studies based on large series, less than 1\% of NSJ cases show complication. ${ }^{5}$ Previous reports have shown that $50 \%$ of the tumors that appear within NSJs are basal cell

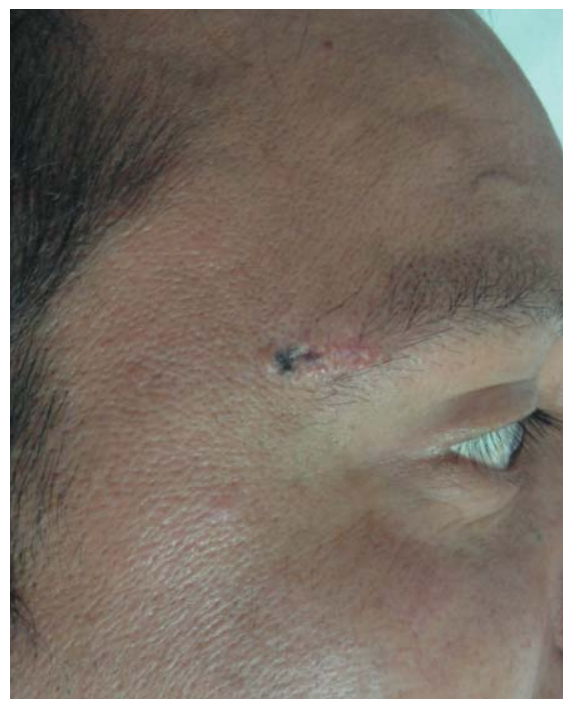

Figure 1: A welldefined, yellowish pink plaque with a cobblestone surface on the tail of the right eyebrow. It presents a blackish macule in its interior

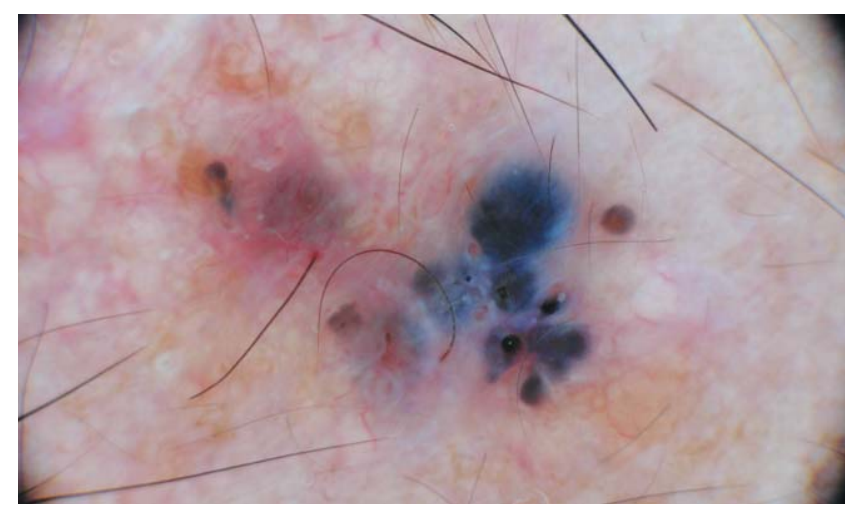

Figure 2: Large gray-blue ovoid nests, of different sizes, not connected to each other. Branched telangiectasias are located between them (Dermalite DL 3, 20X)

carcinomas (mainly trichoblastomas). ${ }^{5,6}$ Other lesions that have been reported include sebaceous carcinomas, leiomyosarcomas, eccrine porocarcinomas, syringocystadenoma papilliferum and malignant melanomas.

Currently, given the low risk of malignization, NSJ excision is recommended only if this complication is suspected. ${ }^{5,6,8,9}$ However, prophylactic NSJ removal before puberty is still accepted.

In the case reported, the pigmentation of the nevus changed, and this raised the possibility of the development of a pigmented trichoblastoma, BCC, or melanoma.

After dermoscopic examination, the hypothesis that a $\mathrm{BCC}$ was present became more convincing due to the presence of large, blue, oval-shaped nests, which is considered to be a major criterion for diagnosing this type of tumor.

These structures are the histological manifestations of pigmented, basaloid cell aggregates proliferating in the papillary dermis, as confirmed by biopsy.

One study in the literature reports the use of dermoscopy to identify the type of tumor present in a

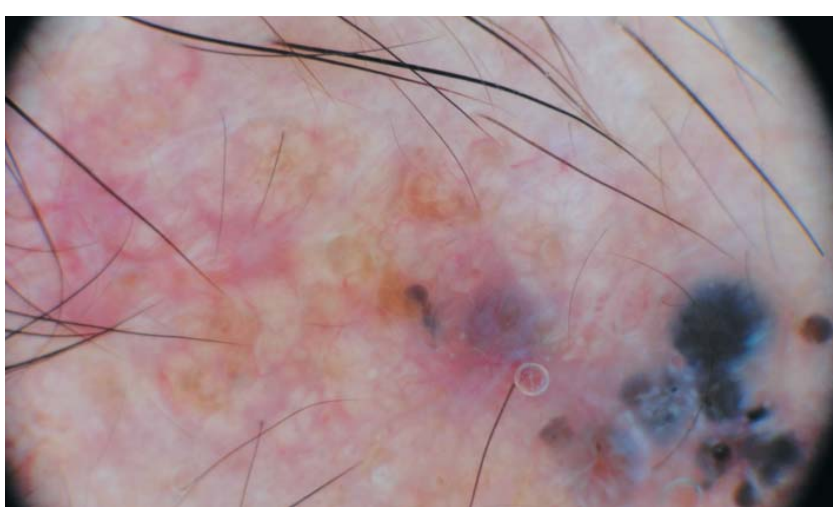

FigURE 3: Globular yellowish structures, grouped to form clusters Fine telangiectasias surround the lobes (Dermalite DL 3, 20X) 


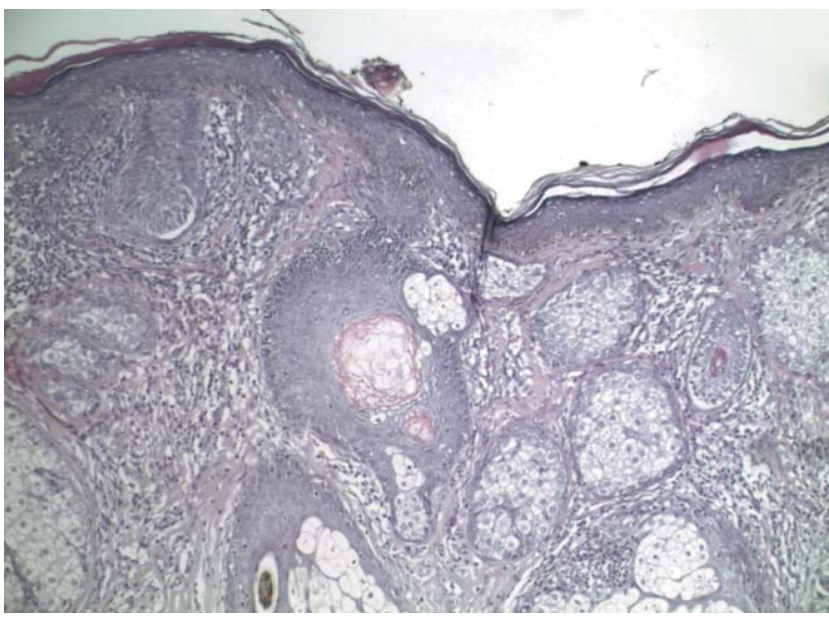

FIGURE 4: Histopathology: Acanthosis and epithelial papillomatosis with hypertrophic sebaceous glands (4x). Solid epithelial lobules infiltrating dermal tissue composed of small basaloid cells and peripheral palisading scalp NSJ. However, according to the authors, dermoscopy was not useful to establish a precise diagnosis because of the special anatomical features of the lesion site. ${ }^{10}$

In our case, dermoscopy was a useful tool to confirm the development of a neoplasm within a facial NSJ and to determine that the tumor was a BCC.

In conclusion, we believe that dermoscopy can be useful in the evaluation of a sebaceous nevus with suspected malignant transformation. The description of this case allows us to better define what type of dermoscopic features of BCC develop within such hamartomas.

Furthermore, we propose to evaluate whether the use of dermoscopy to monitor clinical lesions can assist in the early detection of tumor development, thereby permitting resection at the most appropriate time.

\section{REFERENCES}

1. Pereira LB, Gontijo B, Silva CM. Dermatoses neonatais. An Bras Dermatol. 2001;76:505-37.

2. Neri I, Savoia F, Giacomini F, Raone B, Aprile S and Patrizi A. Usefulness os dermatoscopy for the early diagnosis of sebaceous naevus and diffentiation from aplasia cutis congenital. Clin Exp Dermatol. 2009;34:e50-2.

3. Kim NH, Zell DS, Kolm I, Oliviero M, Rabinovitz HS. The dermoscopic differential diagnosis of yellow lobularlike structures. Arch Dermatol. 2008;144:962.

4. Valenzuela BX, Guevara GE, Hernández TM, Fajardo BD, Solís LG. Tumores asociados con nevo sebáceo de Jadassohn: estudio retrospectivo de cinco años. Dermatología Rev Mex. 2009;53:273-7.

5. Cribier B, Scrivener Y, Grosshans E. Tumors arising in nevus sebaceous: A study of 596 cases. J Am Acad Dermatol. 2000;42:263-8.

6. Jaqueti. Tricoblastoma is the most common neoplasm developed in nevus sebaceous of Jadassohn: a clinicopathologic study of a series of 155 cases. Am J Dermatopathol. 2000;22:108-18.

7. Abe S, Yamamoto Y, Uno S, Andou M, Akasaka T, Mihm MC. Malignant melanoma arising in a sebaceous nevus of the scalp. Br J Plast Surg. 2003;56:171-3

8. Santibanez-Gallerani A, Marshall D, Duarte AM, Melnick SJ, Thaller S. Should nevus sebaceous of Jadassohn in children be excised? A study of 757 cases, and literatura review. J Craniofac Surg. 2003;14:658-60.
9. Barkham MC, Moss C, White N, Brundler MA. Should naevus sebaceous be excised prophylactically? A clinical audit. J Plast Reconst Aesthet Surg. 2007;60: 1269-70.

10. De Giorgi V, Massi D, Trez E, Alfaioli, Carli P. Multiple pigmented trichoblastomas and syringocystadenoma papilliferum in naevus sebaceous mimicking a malignant melanoma: a clinical dermoscopic-pathological case study. $\mathrm{Br} J$ Dermatol. 2003;149:1067-70

\author{
MAILING ADDRESS: \\ Maria Leonor Enei \\ Santiago Polanco 2030. 2do piso. \\ Oficina 10. Iquique, Chile \\ E-mail: leonorenei@vtr.net
}

How to cite this article: Enei ML, Paschoal FM, Valdés G, Valdés R. Basal cell carcinoma appearing in a facial nevus sebaceous of Jadasshon: dermoscopic features. An Bras Dermatol. 2012;87(4):640-2. 